Article

\title{
The Civic Scale: Strategies of Emplacement in Dambudzo Marechera and Ivan Vladislavić
}

\author{
Liam Kruger \\ Department of English, University of Wisconsin Madison, Madison, WI 53706, USA; lkruger2@wisc.edu
}

Received: 15 March 2019; Accepted: 1 May 2019; Published: 10 May 2019

\begin{abstract}
This paper identifies and intervenes in the problems posed by reading postcolonial texts as representative, or encompassing of, the nation with which they are associated. Alternatively, it proposes that reading at the scale of the city offers a method for circumventing the elision of particularity which occurs when the nation, continent or globe are foregrounded in Western or Western-facing responses to these texts. The paper models what such a "scaled-down" reading might look like, attending to Dambudzo Marechera's House of Hunger (1978) and Ivan Vladislavic's Portrait With Keys: Joburg and What-What (2006), and their intricate relationships to the urban spaces of Harare and Johannesburg, respectively. At stake in these analyses are opportunities to identify what Jacques Rancière terms dissensus, or political contestation, rendered in spatial terms. This establishes a pliable counterdiscourse of the city which seeks and discerns meaning not through consensus or "sanctioned representation"; but through the complexities of affective attachments, the plurality of experiences, and the teeming heterogeneity of physical and literary spaces that have been previously flattened.
\end{abstract}

Keywords: city writing; postcolonial literature; dissensus; public space; African novel

This city will follow you. You will wander the same streets and grow old in the same neighbourhoods; your hair will turn white in the same houses. And you will always arrive in this city. Abandon any hope of finding another place. No ship, no road, can take you there. C.P. Cavafy; from The City (Cavafy 2008, trans. Sharon)

\section{The Scale of the City}

There is, at present, no robust and falsifiable theory of literature and public space. While there is considerable scholarship being generated on the relationship between the two, the tendencies that I've observed in my reading are a reliance on either a Romantic notion of the genius loci, or 'spirit of place,' transformed in the contemporary urban moment into the practice of psychogeography; an invocation of the old saws of such post-war urban theorists as Michel De Certeau, Henri Lefebvre, and, to a lesser extent, Gaston Bachelard; or else an investment in whichever branch of human geography is currently in vogue.

This is an observation, and not a criticism; it is not the purpose of this paper to generate such a robust and falsifiable theory, and indeed this writer does not know what such a theory would look like. Furthermore, what follows will to a greater or lesser extent be guilty of succumbing to some, if not all three of the abovementioned tendencies. I mention this theoretical lacuna, however, to suggest that we might revise some axioms of contemporary writing on place, literature, and postcolonialism. First, and by now uncontroversially, Fredric Jameson's 1986 claim that "third-world texts, even those which are seemingly private and invested with a properly libidinal dynamic necessarily project a political dimension in the form of national allegory;" (Jameson 1986, p. 65) and second, Benedict 
Anderson's almost universally cited assertion of 1983 that the rise of print culture, and specifically the rise of novels and newspapers, is the condition of possibility for the production of an imaginary shared and exclusive collectivity at the level of the nation state (Anderson 1983, pp. 9-46). Anderson and Jameson's formulations of the tight relationship between the nation and the novel are quite distinct, and, obviously, decidedly more involved than my sentence-long glosses can translate; their formulations have additionally been fairly thoroughly criticised for, in Jameson's case, a naive assumption that postcoloniality is a legibly consistent condition, ${ }^{1}$ and in Anderson's case an investment in the national scale that needn't follow from his premises. ${ }^{2}$

The point here is not to suggest that Jameson or Anderson are wrong, but that the tendency in subsequent criticism has been to take their marrying of the novel with the nation as a critical orthodoxy, which is to say an uncritical orthodoxy, which reifies a categorization of literature along national lines, and which I join many other scholars in intervening against. Where this intervention differs from the majority of scholarship on postcolonial or 'world' literature, however, is that where the field seems at the moment to try and supersede the nation-state, if it does, by privileging the transnational, planetary, or world scale, ${ }^{3}$ it is my preference to scale down towards a somewhat more local and readily apprehensible scope, and put aside worlds and nations, for a moment, in favour of cities ${ }^{4}$-and in particular, cities of the postcolony, given that even non-specialists can fairly readily imagine a canon of New York writers or London writers, but struggle somewhat to do the same for Manila, or Bucharest, or Dar Es Salaam. ${ }^{5}$

The two (African) cities under scrutiny in what follows are Dambudzo Marechera's Harare, as depicted in his best-known collection, The House of Hunger (1978), and Ivan Vladislavić's Johannesburg, as depicted in his experimental travelogue Portrait With Keys: Joburg and What-What (2006). I examine these two texts and the place-names which they use for their settings to demonstrate the utility of reading these settings at the scale of the city, rather than that of the nation, continent, or globe. At stake here is not merely the addition of another heuristic lens to the toolkit of the scholar toggling between close and distant reading, but a question of representation, at once aesthetic and political. The postcolonial text is persistently made to do the work of representing the texture of the postcolonial experience to a, typically, Western or Western-facing audience, which comes with risks for both the writer and the place in question; as Nirvana Tanoukhi suggests,

no sooner do writers accomplish the task of making a convincing or compelling depiction of a particular people and place than they must immediately confront the possibility that their story will be so generalized as to become the sanctioned representation of the life of a country. (Tanoukhi 2013)

\section{See (Ahmad 1994).}

See (Cheah and Robbins 1998).

Gayatri Spivak, Pascale Casanova, David Damrosch, Susan Stanford Friedman, and their subsequent interlocutors have led the way in this process of scaling up.

4 Emily Apter has headed me off at this pass by a number of years in her 2008 'Untranslatables: A World System:'

I would add to this list [of fluctuating, relational, unbordered language worlds] "cities," which treat metropolitan nexuses as metonyms of World. Despite its current seductiveness as unit of analysis, cities remain vulnerable to the charge of depoliticization levied recently by a New Left Review editor: "City spaces are studied in abstraction from their national contexts" and "The wielders of economic power and social coercion remain anonymous." (Apter 2008)

Apter isn't wrong, though I'd point out that in the case of the postcolonial context, the wielders of economic and social coercion will remain anonymous at either the metropolitan or national scale, since those wielders can typically be relied upon to reside in the global north; that being the case there is nothing to be lost in exploring the possibilities of a smaller unit of analysis. And in any case, it's worth exploring why the city should be seductive.

5 It is in this transnational or cosmopolitan spread that the model to follow most sharply deviates from Romantic, or even Jamesian, notions of the genius loci; while I am indebted to its attention to affective space, I am ambivalent about the boundedness and presumed specificity, to the point of untranslatability, of those spaces. 
That elided gap between the compelling depiction and generalized representation is one that I see as analogous to the plugged gap that political philosopher Rancière (2010) identifies with political consensus-which means the "closing [of] spaces of dissensus by plugging intervals and patching up any possible gaps between appearance and reality, law and fact" (Rancière 2010, p. 71). Where consensus is generally understood to "exalt the virtues of discussion and consultation that permit agreement between interested parties," for Rancière it in fact prevents these discussions, consultations, and agreements from taking place because, under the authority of some disembodied, legitimizing consensus, these discussions are read as already having been concluded. Dissensus, by contrast, is a species of productive conflict, "a conflict between a sensory presentation and a way of making sense of it, or between several sensory regimes and/or bodies" (Rancière 2010, p. 139); it is through the negotiation of these conflicts, and the insistence upon making space for these negotiations, that something like a polity can be produced. In this reading, Tanoukhi's 'sanctioned representations' are of a kind with the consensus which prevents conflicting accounts, conflicting representations to be registered-an elision which our attention is drawn to in the dissenting practice of reading national literatures at the level of the city or town, which resists the 'closing of space' which would have a Lagos writer to stand in for Nigerian, or indeed African, literature.

Here a minor paradox emerges: in the event that reading the postcolonial novel at the scale of the city, or town, were to become an institutional orthodoxy, or a consensus, then it, too would be guilty of patching up gaps between appearance and reality, and would be in need of a dissenting renovation. What, then, is to prevent the dissensus of the civic scale to become a consensus? To restate the problem in another disciplinary dialect, there is always the risk that counterdiscourses, in this case the counterdiscourse of the city against the discourse of the nation, "will be recoded, recolonized by these unitary discourses which, having first disqualified them and having then ignored them when they reappeared, may now be ready to reannex them and include them in their own discourses" (Foucault 2003). If national literatures obscure civic or urban literatures, then the civic scale would have its own blind spots-so the question must be asked, why the counterdiscourse of the city, rather than the counterdiscourse of the township, or the domicile, which would have the same dissenting effect? Especially given that my own investment in the civic scale is in part a consequence of another orthodoxy - an investment in and attachment to the modernist novel, which remains a form principally concerned with the experience of urbanity.

My brief answer, which I will extend as this argument progresses, is that where any imagined community much larger than the city risks being irrefutable, any imagined community or representative scale much smaller than the city risks being trivial. The imagined community of the nation offers a consensus that cannot be tested because it is imagined-in Anderson's specific case, it is the impression of simultaneity within and among a reading public that fosters a sense of the nation, such that the absence of any immediate evidence to support such an impression does not necessarily refute it; just because I can't see my fellow nationals doesn't mean that they're not there. A national consensus which can't be argued with, then, is precisely an undemocratic one; this is the state of affairs that J.M. Coetzee laments in his critique of the 1995 Rugby World Cup:

At the World Cup ceremonies, South African spectators learned, some for the first time, that they were Rainbow people, that, whether they liked it or not, they would be represented as such on the world's television screens. As to the terms in which they would be packaged, they would have no say in these. (Coetzee 2001)

While there is no question that the versions of postcolonial cities which are packaged for foreign consumption as tourist destinations likewise overlap but barely with the versions of those cities in which their denizens in fact live, there is at least an immediate ground for contesting that bare overlap-the grounds of the city itself. Raymond Williams, describing the point at which material and demographic accumulation in London reached critical mass in the eighteenth century, observes that 
the contrasts in wealth and poverty were not different in kind from those of the rural order but were more intense, more general, more evidently problematic, in their very concentration into the feverishly expanding city. (Williams 1975)

Adjusting for the fact that the evidence in question is of the predations of a comprador bourgeoisie rather than the bourgeoisie proper, ${ }^{6}$ Williams's observation still holds in the contemporary postcolonial city-and it is the evidently problematic nature of the city which I wish to emphasize here; where the 'national' might not be confronted with the contradictions of their national identity, the citizen must constantly negotiate between the city as imagined and the materially evident city which they inhabit. The scale of the polity at the level of the nation is too great, often, to be effectively polled; any scale of the polity much smaller than the city, while much more pollable, runs the risk of losing political leverage. The polity, or imagined community, of the city, is available for contestation, for dissensus-for Rancière the essence of politics-but is still large enough to signify in broader, that is national and transnational, political, scholarly, and aesthetic, arenas.

This is not to ignore the close historical relationship between nation-building and literature in the wake of the struggle for African independence; as observed by Ngũgĩ wa Thiong'o, the literature proceeding immediately out of the 1962 Makerere African Writers Conference,

in the post-war world of national democratic revolutionary and anti-colonial liberation in China and India, armed uprisings in Kenya and Algeria, the independence of Ghana and Nigeria with others impending-was part of that great anticolonial and anti-imperialist upheaval in Asia; Africa, Latin America and Caribbean islands. It was inspired by the general political awakening; it drew its stamina and even form from the peasantry: their proverbs, fables, stories; riddles, and wise sayings. It was shot through and through with optimism. (Thiong'o 1986) $^{7}$

That optimism would reverse course in relatively short time, as the upheavals that Ngũgĩ describes would coagulate fairly rapidly into neocolonial states of one form or another, which came under sharp criticism from the literary field, inaugurating a generation of African writers concerned with "proclaim[ing] the illegitimacy of the new state and its authority," occasionally being jailed or exiled for their troubles (Olaniyan 2017). Whether operating in the service of national liberation or in post-liberation critique, this literature is still figured as, and often explicitly figured itself as, operating in conversation with the nation and fledgling state.

The difficulty here is that, by virtue of the organization of the means of cultural production in the colonial and indeed postcolonial state, these writers were primarily situated in or dependent upon the colonial city, if not the northern metropole-and as such their critical or revolutionary thrust was undermined, at the national level, by their complicity in uneven distributions of wealth and land, which situation Fanon presciently sketches in Wretched of the Earth; acknowledging the importance of the urban space as the "background against which [revolutionaries] had defined their ideas of the nation and of the political fight," he nonetheless insists that "political action in the towns will always be powerless to modify or overthrow the colonial regime" (Fanon 1963, p. 126). It is this tension between social critique at the level of the nation, and social withdrawal from the rural nation into the metropolis that underwrites, for postcolonial scholars, and for Jed Esty in particular, the particularity

6 What Fanon calls a 'sham' bourgeoisie, "not engaged in production, nor in invention, nor building, nor labour; [but] is completely canalized into activities of the intermediary type" (Fanon 1963).

7 Although, Ngũgĩ continues:

But later, when the comprador section assumed political ascendancy and strengthened rather than weakened the economic links with imperialism in what was clearly a neo-colonial arrangement, this literature became more and more critical, cynical, disillusioned, bitter and denunciatory in tone. 
of postcolonial fiction, who reads in the fictions of Ayi Kwei Armah, Wole Soyinka, and James Joyce, a dramatization of the struggles between "ethical selfhood and aesthetic freedom" and "the burden of national representation" (Esty 1999, p. 58). It is precisely by the assumption of the national frame when engaging in the interpretation of postcolonial literature that this struggle is overlooked, or brought to a premature conclusion; in what follows I mean to offer some notes on what becomes available to the critic when this national struggle is deferred in favour of a more local reading of urban space-with the understanding that this locality is only made meaningful by its specific embeddedness in a broader, and perhaps cosmopolitan, order.

\section{The City in Marechera}

If the articulation between the nation and the city is present in readings of Dambudzo Marechera, it is more easily located in his uneasy absorption into the canons of African or Zimbabwean literature than in his actual output. Marechera, a Zimbabwean writer born in what was then Southern Rhodesia under the settler-colonial regime of Ian Smith, produced the majority of his writings in the late 1970s and early 1980s, immediately before and after the arrival of Zimbabwean independence; his writing was marked by a self-referential, avant-garde aesthetic and a pessimism about the postcolonial dispensation at odds with post-liberation optismism. Despite his House of Hunger having been canonized early on within the Heinemann African Writers Series and becoming the first and only African recipient of the Guardian Fiction Prize in 1979, early reviews by contemporaries critiqued the collection-alternately described as a short story collection with a lead novella, or a fragmented novel (Chela 2017) — for its political anomie, for its "decadent avant-garde European attitude and style," (Okonkwo 1981, p. 91) uncomfortable within an emerging field that saw itself as committed to the process of nation-building, (Hamilton 2013, p. 58) and for Marechera's repeated insistence later in his short career that the arrival of Zimbabwean independence had accomplished nothing for the majority of the country (Cairnie and Pucherova 2014, p. 77). His public persona did not overwhelmingly help matters; in one of his better-known interviews, he offered the still-uncomfortable declaration about African literature and his place in it that

I think I am the doppelgänger whom, until I appeared, African literature had not yet met. In this sense I would question anyone calling me an African writer. Either you are a writer or you are not. If you are a writer for a specific nation or a specific race, then fuck you. (Veit-Wild 1992, p. 221)

That discomfort is not absolute, as evidenced by the commercial and critical survival of Marechera's texts both in and out of the African context, nor is Marechera's output absolutely critical or pessimistic. On the contrary, I'd argue that in his practice of tracking continuities between Salisbury and Harare, two names that refer to the same geographical space on either side of 1982, he betrays an affective attachment to those continuities which, on the one hand demonstrate the incompleteness of the anticolonial project, but on the other are what invest that geographical space with the features of placeness, following Yi Fu Tuan's formulation in which "space [is] that which allows movement, [and] place is pause; each pause in movement makes it possible for location to be transformed into place" (Tuan 1977, p. 6). Tuan is here distinguishing between the abstract, Cartesian space through which we move, and place, where we are at rest-indeed where we are rooted. In the context of massive land theft, segregation, pass laws, and exile, this distinction between space as that which you move through, and place as what you stay rooted in, if only briefly, takes on more than semantic weight.

In a short essay from 1985, Fear and Loathing out of Harare, included in the 2009 reissue of The House of Hunger, Marechera defends his failure to explore the Zimbabwean countryside outside of the city now that independence has made "learn[ing] the life and landscape of Zimbabwe" possible, without the "queasy paranoia of days gone by:" 
Anyway, what can beat a disco fracas at Jobs, a merry romp on the Playboy dancefloor, a Rabelaisian Bacchanalia in the Makabusi Beer Hall, a snoring/drunken bliss in the cells under the eye of kindly policemen, the night and day (almost altruistic) parade of prostitutes, drunks, beggars, down and outs, thieves, con-men, deceiving and deceived husbands (parading to the jingle of cents and crisp protest of dollar notes)? Ah Harare. Its mysterious method of living out of a suitcase, living in anonymously cheerless but expensive blocks of flats, living no longer on borrowed time as in the past but on borrowed money, hire purchase, the black market and the small advances one may rarely extract from the employer's reluctant clenched fist. Harare, where a scream in the night is the signal for all shutters to come down-it's none of my business who is murdering whom. (Marechera 2009, p. 263)

The essay is a lesser-known work of Marechera's, and concludes with a commitment to 'weaning' himself of the 'Hararean breast' following a brief, belated excursion into the countryside - a commitment not to be fulfilled in his biography or in the book, since he would die of HIV-related complications in Harare two years later, and the two pieces which follow on from Fear and Loathing, and which conclude the volume, are likewise centred on Harare and its attractions. While it is one of his few works to explicitly perform the debate between the city and the country that Holston and Appadurai stage, offering a briefly and eventually-abandoned encomium of the city with its "nightlife, hotels, and night-clubs" against "Victoria Falls, Great Zimbabwe, Lake Kariba, Lake Kyle, Chimanimani, Vumba and a host of other places" which Marechera has never visited, asserting that "the country's own charms excite no response in the citizen's armoured heart," I'm more interested here in those urban charms which clearly do get a response out of Marechera, armour or no. Marechera's process here of naming and listing has the effect of asserting his familiarity with and authority over the space being described-and of the space's authority over him, given his difficulty in weaning itself of what it offers. Writing of another African city a couple of hours south, Achille Mbembe and Sarah Nuttall describe the metropolitan formation

in the sense used by Max Weber, Georg Simmel, Walter Benjamin, and others, that is, a capitalist formation closely tied to the money economy and individuality, to calculability and fortuitousness. Metropolitan existence here is "displayed" not necessarily through exhibitions or parks, but via an enticing array of consumer labels and products [... ] From this perspective, what passes in the eyes of Johannesburg's fiercest critics as crass material trappings could very well be understood as an aesthetic of plenitude. (Mbembe and Nuttall 2004, p. 365)

My purpose here is not to join Mbembe and Nuttall in their apologia for the materialism of the postcolonial city. The things around which Marechera builds his culture, twenty years before Mbembe and Nuttall's writing, are not only, 'crass material trappings' but people, and ways of living, which do crowd together, and do hypnotize the spectator, but perform the aesthetic of plenitude, if they do, in spite of inhabiting a context of profound austerity. Rather, I mean to push back against a reading of the postcolonial urban formation that would insist upon its particularity, or its exceptionalism; the litanies, the attachments, are consistent here with urban modernity as theorized from a mid-century European hegemony. The piling up of incongruities—kindly policemen, altruistic thieves, cheerless expense-resolve in a moment of equivalence, in which 'Bacchanalia' and 'Makabusi' become signifiers of even weight, contra the still-prevailing logic that figures postcolonial metropolitan existence and postcolonial cultural production as an anxious compromise between 'Western' and 'local' form and content; ${ }^{8}$ to the extent that the closing moment at once registers the uneasiness and the atomization of a community in which the 'bystander effect' is in play, and at the same time offers it as a naturalized smoothed-over feature of that community-'Ah, Harare' - rather than as a moment of rupture. There's a social critique here, but a fondness for that society in the same movement, an investment in the given

$8 \quad$ See particularly (Appiah 1991). 
and the immediately available in the civic context as opposed to their merely promissory note of the natural charms that, Marechera is told, Zimbabwe offers at the national scale.

This same attachment is reproduced in Marechera's The House of Hunger, the largely plotless but nonetheless violent, scatological, and pessimistic novella that either furnishes his best-known collection with its title, or anchors his fragmented novel. The narrator, having picked up his things and left his house, following a violent scene between his sister-in-law and his brother, encounters Harry, a childhood acquaintance while wandering in the direction of a township bar:

His arm swept the panorama of barbed wire, whitewashed houses, drunks, prostitutes, the angelic choirs of God-created flies, and the dust that erupted into little clouds of divine grace wherever the golden sunlight deigned to strike. His god-like gesture stopped abruptly-pointing straight at the stinking public lavatory.

'What else is there, man?' he repeated.

I think I saw his point.

Immaculate had once asked me the same question-but with a very different emotion from that of her white-chicked brother. She and I had gone down the valley and crossed the river and walked up the ancient stone tracks that led up to the old fortifications which our warlike ancestors had used in time of war. The soft skin stretched effortlessly over the pain behind her delicate oval face. We were looking down over the valley, down upon the township in which we lived.

'What else is there?' she repeated.

And her hands were hurting me. No photograph can ever record the fire of that moment. But I-the fool! — clutched at the tiny straw of loathing for her. It was not possible that a being like her could have been conceived in the grim squalor of our history. She made me want to dream, made me believe in visions, in hope. But the rock and grit of the earth denied this. (Marechera 2009, pp. 49-50)

Here, again, we see the litany, the incongruities, and the affective ambivalence which seems at once to evaluate the available and find it lacking, and to remain attached to it. There is also a disavowal, albeit a subsequently repented-of disavowal, of futurity here, paired with a dismissive sexism which dogs much of Marechera's writing, about which more shortly. The fortifications from which the narrator and Immaculate observe their township are of a piece with the touristic charms which fail to excite Marechera's interest in his later essay, large stone structures found throughout the country, built between the eleventh and fifteenth centuries by the historical Kingdom of Zimbabwe. Archaeologists working on these sites came under intense pressure from Ian Smith's Southern Rhodesian administration to suppress any findings that might suggest the obvious and accurate interpretation that complex, wealthy, and indeed urban civilization existed in Zimbabwe and Zambia prior to their colonization; for that exact reason, these sites would subsequently become important to narratives of Zimbabwean cultural nationalism, eager to demonstrate the development of Shona culture prior to the colonial period. Marechera here offers a rereading of that narrative. While the township might appear as provisional, as fleeting, and as unsightly relative to the old stone fortresses, as the public lavatories appear to Marechera's narrator and Harry from the front step of the bar, it's also what's there.

There's a commitment to, and affection for, that which is readily available as against what used to be there or what might yet be there, in Marechera, which might simply be a postcolonial fatalism, but which I'd posit as a potential site of civic, sensible encounter-in which a dissensus between Immaculate's optimistic visions and the grim squalor and rock and grit is made possible. Immaculate's proleptic repetition-which is a repetition of the question 'What else is there?' within the body of the text but precedes the utterance that it repeats in the chronology of the story-might offer some clue as to how that dissensus is composed, in which the distance of chronology, and indeed history, is cancelled, and flattened into a series of adjacent utterances. While the context of Immaculate's 'what else is there?' 
is meant to suggest satiation, as against Harry's question which gestures towards the township as a site of insufficiency, as the collection's eponymous hunger, I'd suggest that the distorted chronology collapses the distance between the two poles of this oscillation between dearth and glut, between satiation and hunger, such that Harry and Immaculate are, in fact, asking the same question-in which the game before Marechera's narrator may be crooked, but it also happens to be the only game in town.

I draw my notion of 'cancelled distance' from Ian Baucom's essay 2005 'Township Modernism', ${ }^{\text {' }}$ who himself draws it from Benjamin's discussion of Baudelaire's fascination with the backgrounds of Constantin Guys in his 'Painter of Modern Life' and 'Salon of 1859,' in which the pivot of modernity is articulated by a pre-modernist aesthetic of distance and 'magical' significance as against a properly modern blasé aesthetic which arrives "when the gap between a collectivity's historical experience and its horizon of expectation simultaneously widens and collapses; when, that is, a collective anticipates that a radically novel future is rushing in on it, has, indeed, already begun to arrive" (Baucom 2009, p. 230). For Baucom this is the melancholy but watchful gaze of Baudelaire's courtesans, of Benjamin's backwards-glancing angel of history, and, I would suggest, Marechera's narrator-with the provision that Marechera's vision is only interested in that portion of the future which has already arrived, with the tangible rock and grit as opposed to the distant prospects of Immaculate's visions and hope; an investment in the perpetual present of what-is-there.

Marechera's 'Rabelaisian fracas' is in fact Baudelarian, his gaze fixed "at the horizon, like a beast of prey; the same wildness, the same indolent distraction, and also at times the same fixity of attention" (Baudelaire 1955). The simultaneous widening and collapsing of horizons is precisely what Marechera performs, a flattened but beguiling vision of the modern city, irrespective of where that city might be. Baucom's project, and to an extent my own, is to extend the categories of modernism and modernity to those sites which might seem to be excluded from them;

[the township] subject, [the township] space, and [the township] look, are not in fact, the subjects modernity leaves out, the spaces modernity leaves behind...rather these are the subjects, spaces and looks of modernity from and within and on itself, the immanent actors, zones, and views on and of a global modernity whose magic and whose distance have been pierced. (Baucom 2009, p. 231)

I would go further than Baucom, however, in suggesting that his 'township modernism' is simply modernism. Inasmuch as the postcolonial city—and with some slight modifications, the modern city writ large-is materially impossible without the cheap proximal labour and depressed property prices that the township, Medina, or reservation is composed of, the township and the city are best understood as a unified entity; far from being two spaces with a Manichean divide between them, the township and the city are one and the same place, so interpenetrated that one is unimaginable without the other, in spite of the efforts in the colonial city to suppress the marks of that dependency.

I want to be careful here of sidestepping the charge that anthropologist Jim Ferguson levels at some postcolonial scholarship-which observes that "anthropologists today, working to combat old stereotypes, are eager to say how modern Africa is ... many ordinary Africans might scratch their heads at such a claim" (Ferguson 2005, p. 174). Likewise, one might question the modernity, and modernism, respectively, of Harare and Marechera's vision of it. Nor do I wish to suggest here that Marechera's commitment here to the local scale and flattened potentiality is reproducing the characteristics

9 My decision to use the language of the civic scale in spite of the fact that Marechera is here talking about a township rather than Harare 'proper' is not, or not only, an intervention against Fanon's construction of the colonial city as a Manichean space, divided between the "'native" quarters, the shanty town, the Medina, the reservation ... a disreputable place inhabited by disreputable people," and the colonist's sector, "a sector of lights and paved roads ... a white folks' sector, a sector of foreigners" (Fanon 1968). Baucom, it should be said, offers in 'Township Modernism' a productive rereading of Fanon which concedes his commitment to the national scale but complicates it by suggesting that the production of the nation in Fanon is an ongoing, dialectical process, rather than the static, empty cultural homogeneity which nationalism is popularly identified with-this to develop the thesis that modernist flourishes in a township writer are not borrowed, but rather "paradigmatic of a global modernity." (242). 
of the foreshortened horizon that Benjamin identifies in the modernity of Baudelaire-such that we're forced to posit that modernity generates the same formal representation of itself wherever it emerges and Marechera is merely another fabricator of a vulgar modernism in a postcolonial context. Instead I'm arguing that Marechera's citational and formal use of 'modern' and 'modernist' figures is best understood as an agential strategy of what Neil Smith calls scale-bending, the process whereby "entrenched assumptions about what kinds of social activities fit properly at which scales are being systemically challenged and upset," made possible in a period in which "an inherited territorial structure no longer fulfils the function for which it was built, develops new functions, or is unable to adapt to new requirements and opportunities" (Smith 2004, p. 201). This is precisely, in spatial terms, Ranciere's dissensus-effecting what he identifies a 'redistribution of the sensible,' in which the given correspondences of 'functions, places, and ways of being' are disturbed; and it is with respect to this disturbance that Marechera's fiction conforms to Jameson's understanding of modernism: "oppositional art ... ugly, dissonant, bohemian, sexually shocking" (Jameson 1998, p. 18). Marechera's challenging of the national or continental scale in favour of the local-albeit a local which he wishes to attach to a universalism beyond a 'specific nation or specific race'-is here a tacit rebuke to an obsolete or inappropriate territorial structure, and a reinvestment in the ambiguous opportunities and attachments of the urban space.

\section{Vladislavić and the City}

We may perhaps better test Baucom's identification of the township aesthetic with modernity and avoid or at least forestall head-scratchings by reading Marechera against and alongside a writer from Fanon's "sector of lights and paved roads where all the trash cans constantly overflow with strange and wonderful garbage, undreamed-of leftovers.... [the] white folks' sector" (Fanon 1968). Ivan Vladislavić, a white South African writer based in Johannesburg, has been publishing since 1993 - after the formal end of apartheid, but before the first democratic elections of the new Republic of South Africa. His work is well-received critically, although it has been slow to circulate outside of South Africa; it is only with his being awarded the Yale-based Wyndham-Campbell Literature Prize in 2015 that critical attention to his work in the global north has begun to respond to his myriad output-postmodern allegories, essayistic reflections, photojournalism, novellas, which perhaps unsurprisingly make a habit of resisting easy generic classification. While Vladislavić's writing far more explicitly thematises its commitment to the urban scale, and specifically its commitment to Johannesburg, than Marechera's, what these writers have in common is a particularity-protean in Vladislavić, iconoclastic in Marechera-that results in a pre-emptive resistance to the possibility of becoming 'sanctioned representations' of much of anything. The vignettes that compose Portrait with Keys: Joburg and What-What are explicitly concerned with the problem of Johannesburg, a space which carries the scars and traces of apartheid city planning on the one hand, but also constellates a series of affective attachments formed within and against that framework. The text has been republished in the global north as Portrait with Keys: the City of Johannesburg Unlocked, flattening somewhat the semantic fluidity of the original title, losing its self-consciously local idiom-Johannesburg rather than Joburg-and leading one to wonder what is being unlocked for a foreign audience that a local audience will not have access to. It is perhaps characteristic, then, that Portrait with Keys begins with a locking-up:

When a house has been alarmed, it becomes explosive. It must be armed and disarmed several times a day. When it is armed, by the touching of keys upon a pad, it emits a whine that sends the occupants rushing out, banging the door behind them. There are no leisurely departures: there is no time for second thoughts, for taking a scarf from the hook behind the door, for checking that the answering machine is on, for a final look in the mirror on the way through the hallway. There are no savoured home-comings either: you do not unwind into such a house, kicking off your shoes, breathing the familiar air. Every departure is precipitate, every arrival is a scraping-in. (Vladislavić 2006, p. 11) 
Vladislavić, in this opening litany of negations, inveighs against the absence of a particular kind of familiar home-making gestures in contemporary Johannesburg, a consequence of the rise of what Tejumola Olaniyan calls 'garrison architecture,' itself a consequence of the privatization of most basic services in the postcolonial context, in which the "gross rural-urban divide and rural impoverishment" demands the "stressful, alienating, and dehumanizing lengths the middle class and rich in the city must go to protect themselves and their property" (Vladislavić 2006, p. 19). This underscores the care that must be taken in any transplantation of hegemonic European theorists of placing and dwelling to the postcolonial context. I think particularly here of Gaston Bachelard's Poetics of Space, which risks in these contexts a weightlessness, an abstraction which, in assuming that the house is a "tool for analysis of the human soul" (Vladislavić 2006, p. 37) forgets the unhoused, the packed-together, the garrisoned, and those homes with porous or penetrated borders. Which is not to say that these theorists are not useful, but that there are particularities to urban space in the postcolony which theory developed in the hegemonic metropolitan north isn't self-evidently equipped to work through. We see the obverse side of this more literally unheimlich dwelling early on in The House of Hunger, in which a scene of domestic violence is punctuated by a dead cat being thrown through the narrator's living-room window by a group of children, underscoring the point that if the home is a particular corner of the world, as Bachelard seems to contend, it abuts and overlaps with many others. But just as Marechera engages in the process of home-making outside the home but within the city, 'under the eyes of snoring policemen,' Vladislavić is explicit, in his ambivalent memoir turned writer's diary turned user's manual, about the process of home-making, even as those roots are no longer easily placed in the actual house, even as familiar models of home-making no longer apply:

Long before he invented London, Dickens knew that cities exist primarily so that we can walk around them. [... ] We are entitled to envy Dickens. He lived in a city which offered the walkers "miles upon miles of streets" in which to be lonely. [... ] A stranger, arriving one evening in the part of Johannesburg I call home, would think it had been struck by some calamity, that every last person had fled. There is no sign of life. Behind the walls, the houses are ticking like bombs. (Vladislavić 2006, p. 49)

Marechera and Vladislavić, while unambiguously critical of the spaces they inhabit, nonetheless attempt to imbue those spaces with such human affect as to make them habitable. Says Vladislavić:

This is our climate. We have grown up in the air, this light, and we grasp it on the skin, where it grasps us. We know this earth, this grass, this polished red stone with the soles of our feet. We will never be ourselves anywhere else. Happier, perhaps, healthier, less burdened, more secure. But we will never be closer to who we are than this. (Vladislavić 2006, p. 76)

I want to be careful here, of overstating the optimism of this reading-because while Vladislavić and Marechera do, I think, work more carefully to cultivate the de Certeauvian vision of "a particular pattern of familiar or habitual movement over the skin of the earth, which, if we could see it from a vantage point in the sky, would appear as unique as a fingerprint," (Vladislavić 2006, p. 12) the plaintive echo of Marechera's Harry is still audible in that cultivation-as is Cavafy. Where Mbembe and Nuttall, not unlike the anthropologists that Ferguson gently rebukes, insist that "there is no question that Johannesburg is a city that, from the origins, has symbolized novelty, exuberance, adventurism, and, to a large extent, the possibility of a kind of freedom," (Mbembe and Nuttall 2004, p. 366) it is important to remain mindful of the context in which this liminal freedom, and limited home-making, is achieved-namely,

occasionally and then despite, and not because of, their systematic dehumanization and immiseration under the regime of a predatory transnational capitalism that seeks to erode whatever national and local securities that had been collectively and historically bargained for over previous eras. (Mukherjee 2012, p. 476) 
My purpose here is not to enact what Tanoukhi calls a "a globalistic perversion of the classical theory of reflection," in which "material processes of globalization [are] expressed in dynamics of world-making by literary form" (Tanoukhi 2013, p. 674). To read these accounts of rootedness, of emplacement in Marechera and Vladislavić as, on the one hand, triumphalist narratives of survival in precarity, or on the other, as doomed missives from the global periphery, collapses the oppositional, dissenting nature of these texts into mere evidence for the general and global structures of feeling formed over the past half century of what Jameson (2002) calls "a singular modernity," and which has become yet another, if tacit, consensus. Moreover it neglects the extent to which this singular modernity is not only unevenly distributed spatially, but also in terms of race, gender, sexuality, impairment, and class-such that a consideration of the urban place-making strategies of these two men, Ivan Vladislavić and Dambudzo Marechera, is necessarily limited in its scope, and one which must limit the kinds of globalized generalizations that can be made here. ${ }^{10}$ Let me suggest, however, that there is a way of reading the city, at once overwhelmed and disappointed, that goes back in the history of city writing at least as far back as Baudelaire - and to follow Williams, as far back as Wordsworth's Prelude-which generates a cosmopolitan, transnational tradition that Marechera and Vladislavić are actively and dissentingly involved in, bringing to bear upon it visions of profound urban precarity. What this involvement alerts us to is the fact that from its inception, city writing, and city writing's most celebrated figure in modernity, the flâneur, have always been invested-even and in spite of the received wisdom that street-walking should be objectless and disinterested. Benjamin underscores this reading, and attributes the insight to Baudelaire, who "knew how things really stood for the literary man; as flâneur, he goes to the marketplace, supposedly to take a look at it, but in reality already looking for a buyer." ('Paris of the Second Empire in Baudelaire') Acquisitiveness that is disguised as disinterest, a necessarily commercial approach to reality as a condition of survival under capitalism, is baked into the flâneur; the modern city as a product of the concentration of capital in the wake of the industrial revolution is both the condition of possibility for the flâneur's strolling and also that which impels him into the marketplace, in an attempt to stay afloat. I would go a step further and read these attachments as not only mercantile, but affective-and cruel. In this latter sense I'm drawing on Lauren Berlant's cruel optimism: attachments of desire which subjects "might not well endure the loss of [ ... ] even though its presence threatens their well-being, because [ ... ] the continuity of its form provides something of the continuity of the subject's sense of what it means to keep on living. "(Berlant 2011, p. 24) What's striking, in Marechera and Vladislavić, is an attachment to places and ways of being which are, in all likelihood, not in their best interests-and even so, they stay. Reflecting on his time in Harare, Marechera comments.

The endless round of drink, dance, film, sex and sleep is ultimately demoralising. One begins to ask: is this all there is to my life? To fall into a huge vat of beer is at first exciting, stimulating-drinkable-but then the hour of drowning approaches. (Marechera 2009, p. 265)

It may well be, following Mbembe, that as "capitalism sets about recolonizing its own centre," (Mbembe 2017, p. 179) generating in the hegemonic West states of exception previously particular to the colony and postcolony, that the space Marechera describes is becoming much more common outside of Harare, such that it will make more sense to generate readings of cities alongside one another without reference to, and in spite of, their national contexts. It follows that this present moment is, among other things, one of convergence between the literary tradition of city-writing that Marechera and Vladislavić invoke, and the materially precarious conditions of cities as putatively disparate as Johannesburg and Brussels, Harare and Milwaukee. Which is to say that it may well be that the

10 For a recuperation of the model of the flâneur, which Vladislavić and Marechera more and less explicitly invoke in their writings, from a compulsory masculine and able-bodied subjectivity, see in particular (Elkin 2017; D'Souza and McDonough 2006; Wilson 1992; Campbell 2010; Serlin 2005). 
'critical orthodoxy' of nation and novel is being unpicked, without the need of interventions like this one, by the material fact of trasnational capital eroding the civic commons that undergird national identities, sharpening the tensions between cities and the nations that house them, between cities and the countries that supply them, generating a cosmopolis of precarity, of embattled but dogged attachments - of which Marechera and Vladislavić are but two, quite distinct, indices. The perspective that this heterodoxy offers is exhilarating, but it makes it difficult not to read Marechera, as with Vladislavić, as with Cavafy, as effectively elegiac - even if proleptically, and so perhaps prematurely, elegiac. But the hour of drowning approaches, and the upshot of my own cruel attachments to the Johannesburgs, the Cape Towns, the Harares of this world clues me in to the suspicion that rising tides will be sure to submerge these cities before those of the global north; and my fear is that the question of "what else is there?" will be solved by a drowning of what there is. I don't know of a dissensus, or a scale-bending, that can respond to such a silence.

Funding: This research received no external funding.

Conflicts of Interest: The author declares no conflict of interest.

\section{References}

Ahmad, Aijaz. 1994. Theory: Classes, Nations, Literatures. New York: Verso, pp. 95-124.

Anderson, Benedict. 1983. Imagined Communities: Reflections on the Origin and Spread of Nationalism. London: Verso. Appiah, Kwame Anthony. 1991. Is the Post-in Postmodernism the Post-in Postcolonial? Critical Inquiry 17: 336-57. [CrossRef]

Apter, Emily. 2008. Untranslatables: A World System. New Literary History 39: 581-98. [CrossRef]

Baucom, Ian. 2009. Township Modernism. In Geomodernisms: Race, Modernism, Modernity. Edited by Lauren Doyle and Laura Winkiel. Indianapolis: Indiana University Press.

Baudelaire, Charles. 1955. The Mirror of Art, Critical Studies. Translated and edited with notes and illus. by Jonathan Mayne. London: Phaidon Press.

Berlant, Lauren. 2011. Cruel Optimism. Durham: Duke University Press.

Cairnie, Julie, and Dobrota Pucherova, eds. 2014. Moving Spirit: The Legacy of Dambudzo Marechera in the 21st Century. Munster: LIT Verlag.

Campbell, Fiona Kumari. 2010. Crippin' the Flâneur: Cosmopolitanism and Landscapes of Tolerance. Journal of Social Inclusion 1: 75-89.

Cavafy, Constantine. 2008. Selected Poems. Translated with an introduction by Avi Sharon. London and New York: Penguin.

Cheah, Pheng, and Bruce Robbins, eds. 1998. Cosmopolitics: Thinking and Feeling beyond the Nation. Minneapolis: University of Minnesota Press, p. 6.

Chela, Efemia. 2017. [Temporary Sojourner] How Little Has Changed in Thirty-Nine Years: Efemia Chela Reads Dambudzo Marechera's The House of Hunger. The Johannesburg Review of Books. Available online: https://johannesburgreviewofbooks.com/2017/06/05/temporary-sojourner-how-littlehaschanged-in-thirty-nine-years-efemia-chela-reads-dambudzo-marecheras-the-house-ofhunger/ (accessed on 10 December 2017).

Coetzee, John Maxwell. 2001. The 1995 Rugby World Cup. In Stranger Shores: Essays, 1986-1999. London: Secker \& Warburg.

D'Souza, Aruna, and Tom McDonough, eds. 2006. The Invisible Flâneuse? Gender, Public Space, and Visual Culture in Nineteenth-Century Paris. New York: Manchester University Press.

Elkin, Lauren. 2017. Flâneuse: Women Walk the City in Paris, New York, Tokyo, Venice, and London. New York: Farrar, Straus and Giroux.

Esty, Jed. 1999. Excremental Postcolonialism. Contemporary Literature 40: 2-59. [CrossRef]

Fanon, Frantz. 1963. The Wretched of the Earth. New York: Grove Weidenfeld.

Fanon, Frantz. 1968. The Wretched of the Earth. New York: Grove Press, p. 4

Ferguson, Jim. 2005. Decomposing Modernity: History and Hierarchy after Development. In Postcolonial Studies and Beyond. Edited by Loomba Ania, Kual Suvir, Bunzl Matti, Burton Antoinette and Esty Jed. Durham: Duke University Press. 
Foucault, Michel. 2003. Society Must Be Defended. In Lectures at the Collège De France, 1975-1976. New York: Picador. Hamilton, Grant, ed. 2013. Tracing the Stain in Marechera's 'House of Hunger'. In Reading Marechera. Suffolk: Boydell and Brewer.

Jameson, Fredric. 1986. Third-World Literature in the Era of Multinational Capitalism. Social Text, 65-88. [CrossRef] Jameson, Fredric. 1998. The Cultural Turn Selected Writings on the Postmodern 1983-1998. New York: Verso. Jameson, Fredric. 2002. A Singular Modernity: Essay on the Ontology of the Present. New York: Verso. Marechera, Dambudzo. 2009. The House of Hunger. Essex: Pearson Educated Limited.

Mbembe, Achille. 2017. Critique of Black Reason. Durham: Duke University Press.

Mbembe, Achille, and Sarah Nuttall. 2004. Writing the World from an African Metropolis. Public Culture 16: 347-72. [CrossRef]

Mukherjee, Pablo. 2012. Ivan Vladislavić: Traversing the uneven city. Journal of Postcolonial Writing 48: 472-84. [CrossRef]

Okonkwo, Juliet. 1981. A Review of the House of Hunger. Okike: An African Journal of New Writing, 87-91.

Olaniyan, Tejumola, ed. 2017. State and Culture in Africa: The Possibilities of Strangeness. In State and Culture in Postcolonial Africa: Enchantings. Bloomington: Indiana University Press.

Rancière, Jacques. 2010. Dissensus: On Politics and Aesthetics. London: Bloomsbury.

Serlin, David. 2005. Disabling the Flâneur. Journal of Visual Culture 5: 139. [CrossRef]

Smith, Neil. 2004. Scale Bending and the Fate of the National. In Scale and Geographic Inquiry: Nature, Society and Method. Edited by Robert McMaster and Eric Sheppard. Oxford: Blackwell.

Tanoukhi, Nirvana. 2013. The Movement of Specificity. PMLA 128: 668-74. [CrossRef]

Thiong'o, Ngũgĩwa. 1986. Decolonising the Mind: The Politics of Language in African Literature. London: Heinemann. Tuan, Yi Fu. 1977. Space and Place: The Perspective of Experience. Minneapolis: University of Minnesota Press.

Veit-Wild, Flora. 1992. Dambudzo Marechera: A Source-Book on His Life and Work. Harare: University of Zimbabwe Press.

Vladislavić, Ivan. 2006. Portrait with Keys; Joburg \& What What. Johannesburg: Umuzi Books.

Williams, Raymond. 1975. The Country and the City. London: Oxford University Press.

Wilson, Elizabeth. 1992. The Sphinx in the City: Urban Life, the Control of Disorder, and Women. Berkeley: University of California Press.

(C) 2019 by the author. Licensee MDPI, Basel, Switzerland. This article is an open access article distributed under the terms and conditions of the Creative Commons Attribution (CC BY) license (http://creativecommons.org/licenses/by/4.0/). 